\title{
Migration-Trade NEXUS IN SUB-SAHARAN AFRICA: EVIDENCE FROM A DYNAMIC PANEL STUDY
}

\section{Sunday Elijah}

Department of Economics

Federal University Gusau, Zamfara State

Nigeria.

Department of Economics

School of Business and Economics, Universiti Putra Malaysia

Malaysia.

elijahsundayecons@gmail.com

\section{Hanny Zurina Hamzah *}

School of Business and Economics

Universiti Putra Malaysia

Malaysia.

hannyzurina@upm.edu.my

\author{
Law Siong Hook
}

School of Business and Economics

Universiti Putra Malaysia

Malaysia.

lawsh@upm.edu.my

\section{Shivee Ranjanee Kaliappan}

School of Business and Economics

Universiti Putra Malaysia

Malaysia.

shivee@upm.edu.my

*Corresponding author's Email: hannyzurina@ upm.edu.my

Peer-review under responsibility of 4th Asia International Multidisciplinary Conference 2020 Scientific Committee http://connectingasia.org/scientific-committee/ (C) 2020 Published by Readers Insight Publisher, Office \# 6, First Floor, A \& K Plaza, Near D Watson, F-10 Markaz, Islamabad. Pakistan, editor@readersinsight.net This is an open access article under the CC BY-NC-ND license (http://creativecommons.org/licenses/by-nc-nd/4.0/). 


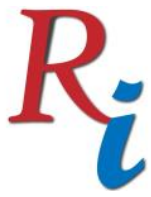

Asia Proceedings of Social Sciences

(APSS)

www.readersinsight.net/APSS

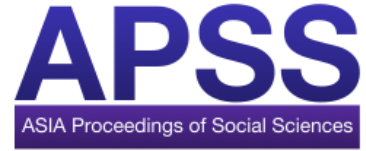

\section{A b s tra c t}

This study examines the impact of migration on trade in SSA region. We used the system generalized method of moments (GMM) estimator with data for 45 sub-Saharan Africa (SSA) countries from the period 1981-2015 to examine the relationship between migration and trade. The econometric results of our model for migration is negative and significant, this vindicated and validated the Heckscher-Ohlin theory. Furthermore, the econometric results of this study for GDP showed it is significant and positive, population is negative and significant, and lastly exchange rate shows it is significant and positive. In general, the findings of this study supported the theories and previous studies. The robustness test showed similar results with the main results of this study. Our model has passed all the diagnostic tests that were conducted, that is, the Sargan, AR1 and AR2 tests, they were all consistent and are in line with the theory. Hence, we can conclude that our results from these estimations are valid and reliable. This study recommended that migration in SSA should be on control and watch list where this will aid in reducing migration in large numbers and some of the migration issues which trade is one of them.

\section{Rese a r ch H igh I ight s}

- This research is focusing on the potential impacts of migrants on trade as it relates to developing countries that are less open to international trade compared to developed countries for which the link has been widely examined.

- The link between migration and international trade is significant to both host and home countries, particularly when it could lead to industrialization in developing countries.

- Some view migration as a positive force because it contributes to the development of the host countries since they get the needed expertise, knowledge and services from both unskilled and skilled labour. Meanwhile for the negative impact, the receiving countries could suffer because of illegal migrants coming into their nations.

- The findings contribute to negative but significant relationship between migration and trade in the case of 45 sub-Saharan countries 


\section{Asia Proceedings of Social Sciences}

(APSS)

www.readersinsight.net/APSS

\section{Graphic a I A b s t r a c t}

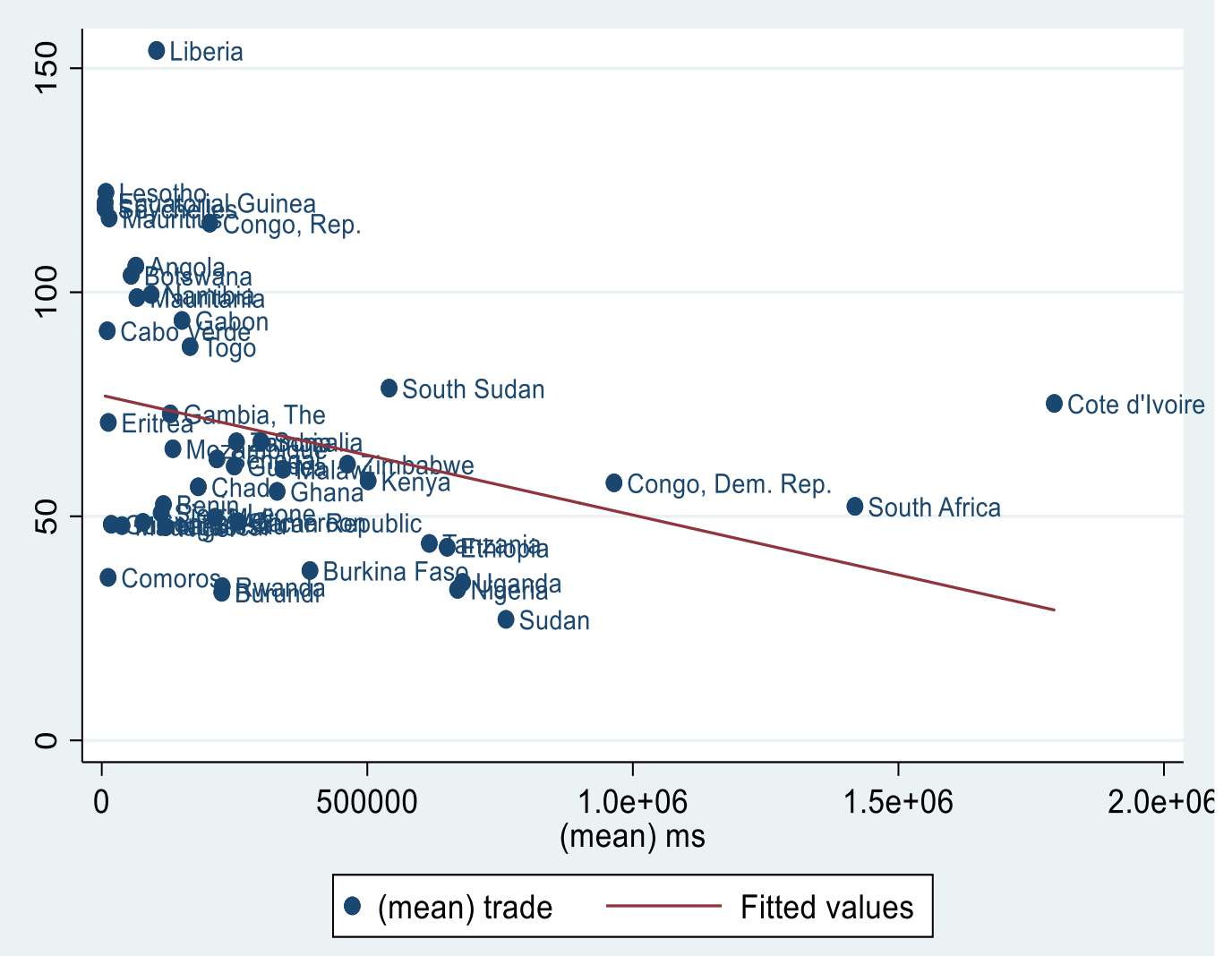

Fig. 1: Scatter plot for Migration and Trade for SSA region

\section{Research Objectives}

The aim of this study is to investigate the impact of migration on trade in SSA from 1981-2015. The economic implication of the SSA migrantion is not studied adequately, therefore, this study is a footstep to fill the void by concentrating on SSA region. Instead of pooling all the developing countries that has different level of income, policies of migration, regions, culture and history as had been the case in a lot of existing empirical research, this study focuses on labour-exporting countries of SSA in other to minimize the possible country-specific heterogeneity. Our study provides insights that may be useful for the formulation of economic and social policies relating to goods and factor markets in developing countries. The shall investigate and bring to light these activities impact, with our hope that the policymakers in SSA region shall consider the issues in their future formulations of policies.

\section{Methodology}

This study followed Tadesse \& White (2013), the specified model is:

$$
T r_{i t}=\beta_{0}+\beta_{1} \operatorname{Tr}_{i, t-1}+\beta_{2} M S_{i, t}+\beta_{3} G D P_{i, t}+\beta_{4} P O P_{i, t}+\beta_{5} E X R_{i, t}+\varepsilon_{i t}
$$




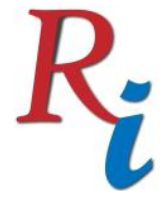

\section{Asia Proceedings of Social Sciences \\ (APSS) \\ www.readersinsight.net/APSS}

From equation (1), taking the natural logarithms of the variable(s) on both sides of the equation gives:

$\ln T r_{i t}=\beta_{0}+\beta_{1} \ln T r_{i, t-1}+\beta_{2} \ln M S_{i, t}+\beta_{3} \ln G D P_{i, t}+\beta_{4} \ln P O P_{i, t}+\beta_{5} \ln E X R_{i, t}+\varepsilon_{i t}$

where: $\operatorname{Tr}$ is trade, $M S$ is migration, $G D P$ is gross domestic product, $P O P$ is population, EXR is exchange rate. $\beta_{1}-\beta_{5}$ are parameters that captures the rate of change between dependent and independent variables. $i$ and $t$ represents the cross-sectional and time period respectively. $\varepsilon_{i t}$ is the error term.

This study used a panel data for 45 SSA countries from 1981-2015, the choice of the country and base year was due to availability of data for the countries used. The data for the period 1981-2015 were averaged on a five years interval basis in other to allow for large cross section of countries and small time period as suggested in generalized method of moment (GMM) technique by Law (2018). Law (2018) gives support to fact that averaging of data help to smoothen the business cycle effect that is inherent in the data. With such information at our disposal, we employed a panel approach for system GMM.

\section{Results}

The empirical results of the estimates displayed that migration is significant and negative, which is in conformity with our scatter plot in Figure 1. This signifies that gross domestic product, exchange rate and population all played vital role in allowing migration in making preparation to decrease trade in SSA region. This result validated Heckscher-Ohlin theory which states that migration and trade are substitute. Our results showed that GDP is positive and significant. This signifies that migration, exchange rate and population all played significant role in supporting GDP preparation to rise trade in SSA region.

This study's results displayed that population is negative and significant, this signifies migration, exchange rate and GDP played decisive role by consenting with population to make plan to lessen trade in SSA region. The results showed that exchange rate is positive and significant, this means that migration, population and GDP all played chief role in agreeing with exchange rate to rise trade in SSA region. All our results validated prior studies. The estimated model passed all the conducted diagnostic tests, i.e., Sargan, AR1 and AR2 test. They are in line and consistent with GMM theory, with these, we can conclude safely our results are reliable and valid.

\section{Findings}

Findings of past studies for migration on trade that regularly concentrate on developed host countries disclosed that migration regularly exercised positive impact on trade. In the situation of SSA, it disclosed an entirely different picture, i.e., migration had a negative impact on trade. Migration is a critical issue for SSA, though, the impact of migration on trade in SSA have not 


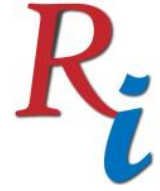

\section{Asia Proceedings of Social Sciences (APSS) \\ www.readersinsight.net/APSS}

been sufficiently studied and addressed, this study is an attempt of filling this lacuna. The variables estimated are theoretically linked to trade, they were carefully considered. In general, the findings of this study validated the expectations and views of theories. This study recommended that migration in SSA should be on control and watch list, this will aid in reducing much addiction by individuals on migration and its issues which has to do with trade.

\section{References}

Beine, M., Docquier, F., \& Rapoport, H. (2008). Brain drain and human capital formation in developing countries: Winners and losers. Economic Journal, 118(528), 631-652. https://doi.org/10.1111/j.1468-0297.2008.02135.x

Elijah, S., \& Musa, A. B. (2019). Dynamic impact of trade openness on the economic growth in Nigeria. International Journal of Engineering and Advanced Technology, 8(5). https://doi.org/10.35940/ijeat.E1087.0585C19

Elijah, Sunday, \& Musa, A. B. (2019). Impact of trade liberalization on economic development in Nigeria based on ARDL approach. Asia Proceedings of Social Sciences, 4(1), 122-124. https://doi.org/10.31580/apss.v4i1.650

Hamzah, H. Z. B. (2012). The Relationship Between Japan and Asean Countries in the Automotive Industry Through Regional Trade Agreements (Issue March).

Karimi, M., Ranjanee Kaliappan, S., Ismail, W., \& Hamzah, H. Z. (2016). The Impact of Trade Liberalization on Tax Structure in Developing Countries. Procedia Economics and Finance, 36, 274-282. https://doi.org/10.1016/S2212-5671(16)30038-7

Karimi, M., Ranjanee Kaliappan, S., Wana Ismail, N., \& Zurina Binti Hamzah, H. (2016). Does Trade Liberalization Affects International Trade Tax Revenue? Evidence from Dynamic Panel Threshold Method. Economic Studies, 25(1). https://www.researchgate.net/publication/301650338

Law, S. H. (2018). Applied panel data analysis: Short panels. Universiti Putra Malaysia Press,43400 UPM, Serdang.

Sandsborg, J., \& Olofsdotter, K. (2017). Trade Effects of Immigration. http://lup.lub.lu.se/luur/download?func=downloadFile\&recordOId=8923692\&file OId $=8923693$

Tadesse, B., \& White, R. (2013). Do African Immigrants Enhance Their Home Nations' Trade With Their Hosts? The Journal of Developing Areas, 47(2), 199-228. https://doi.org/10.1353/jda.2013.0037

UNCTAD/ALDC/AFRICA/2018. (2018). Economic Development in Africa Report 2018. Migration for Structural Transformation. In United Nations Conference on Trade and Development. http://unctad.org/en/PublicationsLibrary/aldcafrica2018_en.pdf 